\title{
The in vivo and in vitro genotoxicity of aromatic amines in relationship to the genotoxicity of benzidine
}

\author{
J.E. Sinsheimer, B.H. Hooberman, S.K. Das, M.D. Brezzell and Z. You

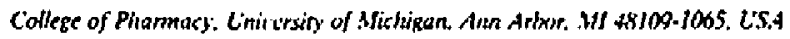 \\ (Received 18 Niowemixi 1991 ) \\ (Accepted a February 1992)
}

Kowords: Benzidine analogucs: Biphenyl amines: Aminostilbenes: Salmonella mutagenicity: Chromosomal aherrations. bone-marrow, in viro

\section{Summary}

Benzidine and 12 related aromaiic amines have been studied for the effects of substituent groups and $\pi$ orbital conjugation on their genotoxicity as measured by their mutagenicity in vitro with Saimonella and by chromosomal aberrations (CA) in vivo in the bone-marrow cells of mice. The in vitro studies indicated increases in mutagenicity with incteases in the clectron withdrawing ability of para' substituents. Mutagenicity also increases with increased conjugation as shown by the degrec of planarity of the biphenyl compounds and by comparing the mutagenicities of biphenyl amines to stibenes as weil as to ethylene bridged diphenyl compounds. The relative in vitro mutagenicity results were not predictive of relative in vivo CA results. The 3 most genotoxic compounds in vivo were the conjugated amines without substituents in the para' position. The $\mathrm{CA}$ values for 4-amirostilbene were exceptionally high. These in vivo tesults indicate increased genotoxicity for benzidine a nalogs without substitution in the para' position.

In a previuus study of a series of commercially available aromatic amines related to benzidine (Messerly et al. 1987). we developed some structure-mulagenicity relationships based upon in vitro results from Ames testing with Salmonclla (Maron and Ames. 1983). In the present study, we are expanding that study to include both in vivo and in vitro structure-genotoxicity relationships. Model aminobiphenyl and aminostilbenc

Correspondence: Dr. J.E. Sinsheimer, College of Phamasy. Universily of Michigan. Ann Arbor, MI 48109-1065, USA. compounds have been synthesized and, together with key compounds from the previous study, have been cualuated for in vivo chromonomal aberrations ( $\mathrm{CA}$ ) in the bone marrow of mice for comparison to their Ames test results.

Because of the recognition of benzidine as a human carcinogen (Zavon et al., 1973; Haley. 1975) and with the resulting limitations that cxist on its manufacturc as well as use (US Federal Register, 1974), there has becn a need for suitable substitutes especially for use in the dye and polymer industrics. Structure-genotoxicity relationships that could be applied to such compounds should be helpful in reaching risk-assess- 
ment decisions concerning their potential hazards.

Planarity and an activated electrophilic site were indicated to be important facturs contributing to the mutagenicity of benzidine analogs in TA98 with S9 activation (Messerly ct al., 1987). It is the purpose of the present investigation to tes! further the effect of these factors in Salmonella sirains TA98 and TA1ON). There is the reported need to supplement the ability of a bacterial test to detect point mutations with a short-term procedure that responds to strand breaks in vivo (Natarajan and Obe, 1986; Shelby, 1988). Therefore, we have also included in this paper a comparison of the genotoxicity of our test compounds in vivo as measured by $C A$ in the bone-marrow cells of mice. Towards these ends we have tested a limited series of 4-aminobiphenyls, 4-amino. stilbenes and related compounds with various substituents in the $4^{\prime}$-position and determined the extent to which their in vitro Salmonella results are predictive of their in vivo $C A$ results.

\section{Materials and methods}

\section{Animals}

Male CD1 mice $10-12$ weeks old $(\sim 30 \mathrm{~g})$ and Sprague-Dawley male rats $(\sim 200 \mathrm{~g})$ wcre purchased from Charles River Breeding Laboratories (Wilmington, MA). Mice were kept 4 per cage and rats 3 per cage with wood chip hedding, were fed chow (Purina) and water ad libitum and were housed 4-5 days prior to the start of the experiment.

\section{Chemicals}

4 Asnisubiplisuryl, 4,4'-ethylemebias(aniline), 2aminofluorenc, 2,7-diaminofluorene and 7,12-dimethylbcralajanthracene (DMBA) were purchased from Aldrich Chemical Company (Milwaukee). 4,4'-Diaminobiphenyl (benzidine) was purchased from Harleco (Philadelphia). 4-Amino4'-chloro-, 4-amino-4'-nitro- and 4-amino-2'. methylbiphenyl as wcll as 4-amino-, 4,4'-diamino-, 4-amino-4'-chloro- and 4-amino-4'-nitrostilbene were synthesized from their corresponding nitro precursors by a Zinin reduction (Porter, 1973) with an excess amount of NaHS in refluxing methanol/water. Reactions for the formation of 4-amino-4'-nitrobiphenyl as well as 4-amino-4'. nitrostilbene were closely monitored to minimize over-reduction while the other arnino compounds were produced by prolonged refluxing to achicve high yields. 4-(2-Phenylethyl)ariline was obtained in nearly quantitative yield after silica gel chromatography by hydrogenation ( $4 \mathrm{~atm}$ ) of 4-nitrostilbene in ethyl acetate with Pd-C (10\%) as catalyst.

In regards to the required nitro intermediates, 4-chloro-4'-nitrobiphenyl was synthesized by the procediure of Beaven et al. (1961). 4,4'-Dinitrobiphenyl was obtaincd from COC Company Inc. (Columbia, SC) and 2-methyl-4'-nitrobiphenyl was synthesized by the reaction of the diazonium salt of $p$-nitroaniline with toluene by the procedure of France et al, (1939). The nitrostibenes were obtained by the Wittig reaction with (4-nitrobenzyl)triphenylphosphonium bromide and the required commercially available 4-substituted benzaldehydes (Aldrich). The method used was modified from that of Geerts and Martin (1960) as illustrated in the following synthesis of $4,4^{\prime}-\mathrm{dj}$ nitrostilbene.

p-Nitrobenzyl bromide ( $2.0 \mathrm{~g}, 9.2$ mmoles) and triphenylphosphine $(2.6 \mathrm{~g}, 9.9$ mmoles) in benzene $(8.0 \mathrm{ml})$ were refluxed for $36 \mathrm{~h}$. The phosphonium intermediate was obtained in $99 \%$ yield by filtering $t$ !:e reaction mixture at room temperature. washing the precipitate thoroughly with benzene and drying under vacuum. To a mixture of $p$-nitrobenzaldehyde $(1.0 \mathrm{~g}, 6.6 \mathrm{mmoles})$ and (4-nitrobenzyl)triphenylphosphonium bromide $(4.5 \mathrm{~g} .10$ mmoles) in methanol, $(20 \mathrm{ml})$ sodium methoxide ( $0.544 \mathrm{~g}, 10 \mathrm{mmoles}$ ) was added in small portions. The resulting suspension was seitrad fors $1 \mathrm{~h}$, riltorest and the precipitate was washed with methanol to yield a mixture of $E$ and Z-stilbene ispmer!s! This mixture together with iodine $(0.2 \mathrm{~g})$ was dissolved in $240 \mathrm{ml}$ of ethyl acetate and heated at reflux for $12 \mathrm{~h}$ to isomerize the $Z$ to the $E$ isomer. The yellow crystals, obtained by filtration at room temperature together with those formed when the mother liquor was condensed to $100 \mathrm{ml}$, were washed with methanol and dried under vacuum to yield $1.56 \mathrm{~g}(87 \%)$ of the desired product: m.p. $298-300^{\circ} \mathrm{C}$ llit. (Geerts and Martin, 196(l), 303-3(4. ${ }^{\circ} \mathrm{C}$.

The synthesized test compounds were purified 
by sifica gel chromatography and characterized by melting point and NMR. Table 1 summarizes the yields of the test compounds as obtained from their corresponding nitro precursors, their melting points and NMR data. All test compounds at $0.02 \mu$ moles showed a single spot under UV light with TLC using prescored silica gel GHLF uniplates (Analtech Inc., Newark, DE) in hexane/ethyl acetate solvent systems.
Mutagenicity

Mutagenicity was determined with Salmonelia strains TA98 and TA100 by the standard plate incorporation procedure with and without Aroclor 1254 induced rat-liver $\$ 9(10 \%)$ activation as outlined by Maron and Ames (1983). Each concentration in DMSO indicated in Table 2 was run at least in triplicate and the dose-response relationship confirmed on a second day. Plates were

TABLE I

YIEL.DS, MELTJNG POINTS, AND PROTON NMR DATA " OF THE SYNTHESIZED TESI COMPOUNDS

\begin{tabular}{|c|c|c|c|}
\hline Compounds & $\begin{array}{l}\text { Yielus } \\
(f)\end{array}$ & $\begin{array}{l}\text { M.p. }{ }^{3} \mathrm{C} \\
\text { (lit. m.p.) }\end{array}$ & Proton NMR (3(x) MHz, CDCl $)$ \\
\hline 4-Amino-4'-chlorobiphenyl & 98 & $\begin{array}{c}129-1,31 \\
(133-134)^{6}\end{array}$ & $\begin{array}{l}3.75(2 \mathrm{H}, \text { br s). } 6.748(2 \mathrm{~L}, \mathrm{~d} . J=8.4 \mathrm{fz}) \\
7.34 \mathrm{~h}(2 \mathrm{H}, \mathrm{d}, J=8.5 \mathrm{~Hz}), 7.369(2 \mathrm{H} . \\
\text { d. } J-8.4 \mathrm{Lz}, 7.449(2 \mathrm{H}, \mathrm{d}, J=8.5 \mathrm{~Hz}) .\end{array}$ \\
\hline 4.Amino-4"-nitrobiphenyl & 55 & $\begin{array}{l}203-204 \\
(203-204)^{b}\end{array}$ &  \\
\hline 4-Aminostilbent & 98 & $\begin{array}{c}147-149 \\
(148-[49)\end{array}$ & $\begin{array}{l}3.749(2 \mathrm{H}, \text { br s). } 6.680(2 \mathrm{H}, \mathrm{d}, J=8.6 \mathrm{~Hz}) \\
6.92(1 \mathrm{H}, \mathrm{d}, J=16.3 \mathrm{~Hz}) .7 .02(1 \mathrm{H} . \mathrm{d}, J=16.3 \\
\mathrm{Hz}) .7 .208(1 \mathrm{H} . \mathrm{tt} . J=8.0 .1 .5 \mathrm{~Hz}) \\
7.332(2 \mathrm{H}, \mathrm{t}, J=8.0 \mathrm{~Hz}) .7 .342(2 \mathrm{H}, \mathrm{d} . \\
J=8.6 \mathrm{~Hz}), 7.473(2 \mathrm{H}, \mathrm{dd}, J=8.0,1.0 \mathrm{~Hz})\end{array}$ \\
\hline 4.4'-Diaminostilbene & 99 & $230-231$ & $\begin{array}{l}3.695(4 \mathrm{H}, \text { be s), } 6.663(4 \mathrm{H}, \mathrm{d}, J=8.5 \mathrm{~Hz}) \\
6.839(2 \mathrm{H}), 7.294(4 \mathrm{H}, \mathrm{d}, J=8.5 \mathrm{~Hz})\end{array}$ \\
\hline 4-Amino-4'-chlorostilbene & 95 & $\begin{array}{l}198-29 n \\
(185-1875)^{c}\end{array}$ & $\begin{array}{l}3.761(2 \mathrm{l}, \mathrm{be} s), 6.673(2 \mathrm{H}, \mathrm{d}, J=8.5 \mathrm{~Hz}) \\
6.851(1 \mathrm{H}, \mathrm{d}, J=16.4 \mathrm{~Hz}), 6.996(1 \mathrm{H}, \mathrm{d} \\
J=16 . \mathrm{Hz}, 7.286(2 \mathrm{H}, \mathrm{d}, J=8.6 \mathrm{~Hz}), 7319 \\
(2 \mathrm{H}, \mathrm{d}, J=8.5 \mathrm{~Hz}), 7.385(2 \mathrm{H}, \mathrm{d}, J=8.6 \mathrm{~Hz})\end{array}$ \\
\hline 4-Amino-4'-nitrostilbene & 45 & $\begin{array}{l}242-244 \\
(244)\end{array}$ & 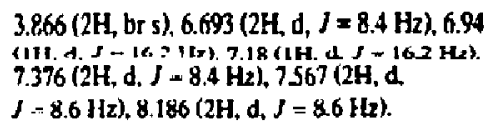 \\
\hline 4(2-Phemylethyl)aniline & 99 & $\begin{array}{l}51-52 \\
(52-54)^{c}\end{array}$ & $\begin{array}{l}2.75-2.93(4 \mathrm{H}, \mathrm{m}) .3 .56(2 \mathrm{H}, \mathrm{br} \mathrm{s}) \\
6.626(2 \mathrm{H}, \mathrm{J}, J=8.3 \mathrm{~Hz}), 6.975(2 \mathrm{H}, \mathrm{d}, \\
J=8.5 \mathrm{HI}), 7.13-7.35(5 \mathrm{H}, \mathrm{m}\rangle\end{array}$ \\
\hline 4-Aminu-2'-methybiphenyl & 95 & oil & $\begin{array}{l}2.286(3 \mathrm{H}, \mathrm{s}), 3.695(2 \mathrm{H}, \mathrm{br} \mathrm{s}) \\
6.727(2 \mathrm{H}, \mathrm{d}, J=8.4 \mathrm{~Hz}), 7.127(2 \mathrm{H}, \mathrm{d} \\
J=8.4 \mathrm{~Hz}, 7.14-7.30(4 \mathrm{H}, \mathrm{m})\end{array}$ \\
\hline
\end{tabular}

Calculation of coupling constants among 1,4 disubstituled phenyl bydrogens was simplified to determine only ortho interactions.

- Zheiltor el ul. (1970).

s Veschambre and Kergumard (1\%6).

d Weast and Grasselli (1989).

c Buckingham (1982). 
TABLE 2

MUTAGENICITY OF AROMATIC AMINES IN Salmmelia typhumurium




TABLE 2 (conlinucd)

\begin{tabular}{|c|c|c|c|c|c|c|c|c|}
\hline \multirow{2}{*}{$\begin{array}{l}\text { Compuunds } \\
\text { Doses } \\
\text { (amoles) }\end{array}$} & \multicolumn{2}{|l|}{ TA48-\$9 } & \multicolumn{2}{|l|}{ TA98+59 } & \multicolumn{2}{|l|}{ TAIM - 59} & \multicolumn{2}{|l|}{ TA $1(0)+S 9$} \\
\hline & $\begin{array}{l}\text { Reveriants } \\
\pm \text { S.D. }\end{array}$ & Skup: " & $\begin{array}{l}\text { Revenuants } \\
\pm \text { S.D. }\end{array}$ & Slupe & $\begin{array}{l}\text { Revertania } \\
\text { 土S.D. }\end{array}$ & Slope & $\begin{array}{l}\text { Revertants } \\
\pm \text { S.D. }\end{array}$ & Slope \\
\hline \multicolumn{9}{|c|}{ 4-Aminostilbene } \\
\hline 0.1 & $41 \pm 11$ & & $391 \pm \pi$ & & $135+7$ & & $1094 \pm 85$ & \\
\hline 0.3 & $42 \pm 5$ & & $500 \pm 118$ & & $155 \pm 21$ & & $2277 \pm 153$ & \\
\hline 0.33 & $5 b \pm 6$ & & & & & & & \\
\hline 0.5 & $41 \pm 2$ & & & & & & & \\
\hline 0.66 & $49 \pm 5$ & & & & & & & \\
\hline 1 & $70 \pm 5$ & & & & & & & \\
\hline 3 & $64 \pm 8$ & & & & & & & \\
\hline \multicolumn{9}{|c|}{ 4.4'-Diaminostilhene } \\
\hline 0 & $2 y \pm 6$ & 0 & $45 \pm 7$ & $295+27$ & $121+14$ & 0 & $128 \pm 17$ & $123 \pm 22$ \\
\hline 0.05 & $25 \pm 4$ & & $64 \pm 3$ & & $121 \pm 6$ & & $152 \pm 15$ & \\
\hline 0.1 & $34+7$ & & $96 \pm 15$ & & $121 \pm 1.4$ & & $144 \pm 24$ & \\
\hline 0.33 & $27+11$ & & $146 \pm 19$ & & $117 \pm 10$ & & $173+18$ & \\
\hline 0.66 & $35 \pm 8$ & & $159 \pm 35$ & & $1.31 \pm 14$ & & $150 \pm 26$ & \\
\hline 1 & $34 \pm 7$ & & $142 \pm 16$ & & $1119+20$ & & $167 \pm 18$ & \\
\hline \multicolumn{9}{|c|}{ 4.Amino-4tehlorostilbenc } \\
\hline 0 & $31 \pm 5$ & 0 & Sी 11 & $14898 \pm 426$ & $115+211$ & 0 & $123 \pm 17$ & $6 \% 99 \pm 215$ \\
\hline 0,005 & $30 \pm 6$ & & $56 \pm 19$ & & $1.36 \pm 1,3$ & & $113 \pm 11$ & \\
\hline 0.01 & $38 \pm 6$ & & $73 \pm 14$ & & $123+24$ & & $162 \pm 32$ & \\
\hline 0.033 & $41+3$ & & $297 \pm 24$ & & $132 \pm 12$ & & $285 \pm 31$ & \\
\hline 0.05 & $4 \pm 10$ & & $628 \pm 132$ & & $112 \pm 15$ & & $396 \pm 33$ & \\
\hline 0.066 & $59 \pm 7$ & & $932+98$ & & $133 \pm 9$ & & $611 \pm 71$ & \\
\hline 0.1 & $46 \pm 11$ & & $1496 \pm 117$ & & $125 \pm 15$ & & $792 \pm 70$ & \\
\hline 0.3 & $57 \pm 11$ & & $2152 \pm 68$ & & $107 \pm 5$ & & $900 \pm 25$ & \\
\hline 033 & $34 \pm 2$ & & & & & & & \\
\hline 0.5 & $58 \pm 13$ & & & & & & & \\
\hline 0.66 & $38+3$ & & & & & & & \\
\hline 1 & $36 \pm 5$ & & & & & & & \\
\hline 3 & $40 \pm 5$ & & & & & & & \\
\hline \multicolumn{9}{|c|}{ 4-Amino-4'-nitrostilbene } \\
\hline () & $33 \pm 6$ & $1038 \pm 24$ & $53 \pm 13$ & $41958 \pm 1127$ & $107 \pm 20$ & 0 & $123 \pm 24$ & $6276 \pm 249$ \\
\hline 0.001 & $46 \pm 4$ & & $68 \pm 8$ & & $88 \pm 14$ & & $122 \pm 21$ & \\
\hline 10.005 & $46 \pm 12$ & & $160 \pm 25$ & & $120 \pm 9$ & & $158 \pm 27$ & \\
\hline 0.03 & $68 \pm 14$ & & $30.1+23$ & & $119 \pm 17$ & & $183 \pm 23$ & \\
\hline 0.02 & $78 \pm 13$ & & $748 \pm 61$ & & $139+17$ & & $257 \pm 29$ & \\
\hline 0.03 & $75 \pm 15$ & & $1320+178$ & & $130 \pm 38$ & & $334 \pm+2$ & \\
\hline $\begin{array}{l}0.033 \\
\text { U.t. }\end{array}$ & $\begin{array}{c}1+4+11 \\
9 \pm \pm 15\end{array}$ & & $\begin{array}{l}1095+202 \\
20.2+261\end{array}$ & & $\begin{array}{l}111+8 \\
121 \pm 14\end{array}$ & & $\begin{array}{l}3 \times 6 \pm 23 \\
432 \pm 02\end{array}$ & \\
\hline 0.046 & $106 \pm 5$ & & $26 \div 7+87$ & & $98+14$ & & $363 \pm 18$ & \\
\hline 0.1 & $161^{3}+16$ & & 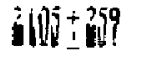 & & $|2|+1\}$ & & $477+70$ & \\
\hline 0.33 & $155 \pm 10$ & & & & & & & \\
\hline 10.66 & $166+16$ & & & & & & & \\
\hline 1 & $199+24$ & & & & & & & \\
\hline \multicolumn{9}{|c|}{ 4.(2.Phenylethyl)aniline } \\
\hline 0 & $30 \pm 12$ & 0 & $53 \pm 18$ & $82 \pm$ & $109+111$ & 0 & $116 \pm 15$ & 150 \\
\hline 0.01 & $39 \pm 5$ & & $74 \pm 3$ & & $123 \pm 5$ & & $1+4 \pm 22$ & \\
\hline 0.1 & $3 !+13$ & & $65 \pm \quad 9$ & & $120 \div 17$ & & {$[6 \pm \pm 47$} & \\
\hline 0.33 & $3 x \pm 6$ & & $85+11$ & & & & & \\
\hline 0.5 & $28+5$ & & $91+9$ & & $109+1 \%$ & & $211 \pm 73$ & \\
\hline 0.66 & $t h \pm 2$ & & $112 t 4$ & & & & & \\
\hline 1.0 & $36 \pm 14$ & & $140 \pm 18$ & & $307 \pm 17$ & & $2 R 4 \pm 106$ & \\
\hline 1.5 & & & & & $75 \pm 8$ & & $348=34$ & \\
\hline 2.0 & $3 \pm 4$ & & $131 \pm 25$ & & $41 \pm 18$ & & $325 \pm 17$ & \\
\hline
\end{tabular}


TABLE 2 (continued)

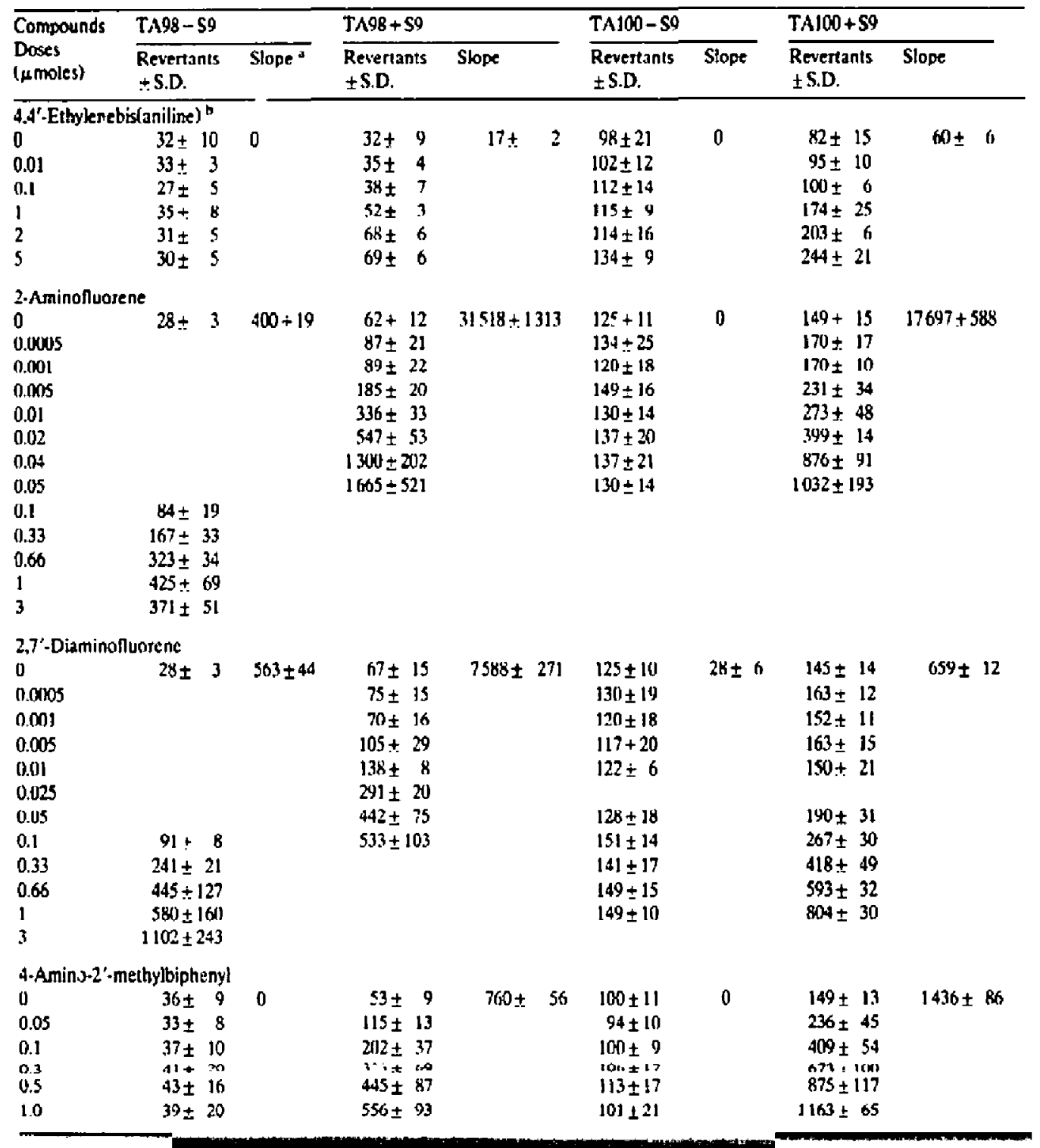

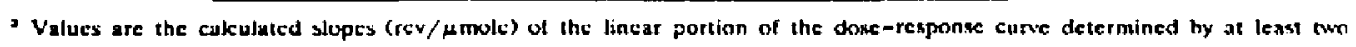
independent experiments.

Dala frost Mescerly et al. (1987).

Notes to toble 3:

- Tolal chromatid and chromosome gaps at each concentration per 100 cells wert recorded but not included as aberrations.

n Celis with at least 1 aberration. Results are for 4 animals al each concentration (100 cels/animal) except where noted.

- Results at each concentration weze comparted to those of the contsot using Dunnett's test (" $P<0.65$ and $=* P<0.01$ ).

d of the 4 unimals died at this concentration.

c All 4 animals died ut this concentration. 
TABLE 3

CHROMOSOMAL ABERRATIONS INDUICED BY AROMATIC AMINES IN BONE MAARROW CELLS OF MICE

\begin{tabular}{|c|c|c|c|c|c|}
\hline \multirow{2}{*}{$\begin{array}{l}\text { Trealment } \\
\text { (mg/kg) }\end{array}$} & \multirow[t]{2}{*}{ Gaps ${ }^{2}$} & \multicolumn{2}{|c|}{ Aberrations/cell } & \multirow{2}{*}{$\begin{array}{l}\text { Aberrant cells }(f,)^{\mathrm{B}} \\
(m e a n \neq \text { S.D. })^{\mathrm{f}}\end{array}$} & \multirow{2}{*}{$\begin{array}{l}\text { Mitotic indices (Sc) } \\
\text { (mean + S.D.) }\end{array}$} \\
\hline & & $\begin{array}{l}\text { Chromatid } \\
\text { type }\end{array}$ & $\begin{array}{l}\text { Chrumosime } \\
\text { type }\end{array}$ & & \\
\hline $\begin{array}{l}\text { Solvent control } \\
\text { DMSO }\end{array}$ & 3 & 0.010 & 0.10001 & $1.00+0.82$ & $3.51 \pm 0.3$ \\
\hline $\begin{array}{l}\text { 4-Aminobiphenyl } \\
25 \\
100^{\circ}\end{array}$ & $\begin{array}{l}3.25 \\
0.67\end{array}$ & $\begin{array}{l}11.028 \\
0.067\end{array}$ & $\begin{array}{l}0.000 \\
0 .(x+3)\end{array}$ & $\begin{array}{l}2.75+0.46 * \\
7.00 \pm 1.00 \cdots\end{array}$ & $\begin{array}{l}3.62 \pm 11.37 \\
1.69 \pm 0.25 * *\end{array}$ \\
\hline $\begin{array}{l}4,4^{\prime} \text {-Diaminobiphe } \\
10 \\
25 \\
50 \\
190 \\
125\end{array}$ & $\begin{array}{l}\text { enyl } \\
5.50 \\
6.25 \\
6.75 \\
6.25 \\
7.75\end{array}$ & $\begin{array}{l}0.013 \\
0.020 \\
0.035 \\
0.043 \\
0.1138\end{array}$ & $\begin{array}{l}0.000 \\
0.003 \\
0.003 \\
0.008 \\
0.023\end{array}$ & $\begin{array}{l}1.25 \pm 0.50 \\
2.25 \pm 0.50 \\
3.75 \pm 0.50 \cdots \\
5.00 \pm \pm 0.82 \cdots \\
6.001 \pm 0.82 \cdots\end{array}$ & $\begin{array}{l}3.71 \pm 0.16 \\
2.69 \pm 0.19 * * \\
2.35 \pm 0.20 * * \\
2.63 \pm 0.33 * * \\
2.62 \pm 0.41 * *\end{array}$ \\
\hline $\begin{array}{l}\text { 4-Amino-4'-chloro } \\
25 \\
100^{\circ}=\end{array}$ & $\begin{array}{l}\text { obiphenyl } \\
3.00\end{array}$ & 0.033 & 0.000 & $300 \pm 11.82 * *$ & $2.31 \pm 0.16 * *$ \\
\hline $\begin{array}{l}\text { 4.Aumino-4'-nitrob } \\
25 \\
100\end{array}$ & $\begin{array}{l}\text { biphenyl } \\
3.00 \\
4.00\end{array}$ & $\begin{array}{l}0.018 \\
0.033\end{array}$ & $\begin{array}{l}0.000 \\
0.008\end{array}$ & $\begin{array}{l}1.75 \pm 0.50 \\
4.00 \pm 0.82 * *\end{array}$ & $\begin{array}{l}2.57 \pm 0.40 * * \\
1.77 \pm 0.24 \cdots\end{array}$ \\
\hline $\begin{array}{l}\text { 4-Aminostilbene } \\
10 \\
25 \\
100^{\mathrm{J}}\end{array}$ & $\begin{array}{r}3.00 \\
5.25 \\
11.00\end{array}$ & $\begin{array}{l}0.030 \\
0.085 \\
0.303\end{array}$ & $\begin{array}{l}0.000 \\
0.013 \\
0.023\end{array}$ & $\begin{array}{r}2.75 \pm 0.50 * * \\
8.50 \pm 1.29 \cdots \\
20.33 \pm 2.108 * *\end{array}$ & $\begin{array}{l}2.77 \pm 0.38 * \\
2.65 \pm 0.35 \cdots \\
1.50 \pm 0.24 \cdots\end{array}$ \\
\hline $\begin{array}{l}\text { 4,4'-Diaminostilbe } \\
25 \\
100\end{array}$ & $\begin{array}{l}\text { ente } \\
5.25 \\
4.50\end{array}$ & $\begin{array}{l}0.023 \\
0.025\end{array}$ & $\begin{array}{l}\text { D.0.0 } \\
0.040\end{array}$ & $\begin{array}{l}2.25 \pm 0.50 \\
250 \pm 1.00\end{array}$ & $\begin{array}{l}2.85 \pm 0.38 * \\
2.58 \pm 0.36 \cdots\end{array}$ \\
\hline $\begin{array}{l}\text { 4Aminu-t'-chlor } \\
25 \\
100\end{array}$ & $\begin{array}{l}\text { ostilbent } \\
2.50 \\
6.25\end{array}$ & $\begin{array}{l}0.020 \\
0.028\end{array}$ & $\begin{array}{l}0.000 \\
0.005\end{array}$ & $\begin{array}{l}2.10 \pm 0.82 \\
3.25 \pm 0.50 \cdots\end{array}$ & $\begin{array}{l}2.66 \pm 0.09 * * \\
2.28 \pm 0.08 * *\end{array}$ \\
\hline $\begin{array}{l}\text { 4-Amino-4' nitros } \\
25 \\
100\end{array}$ & $\begin{array}{r}\text { stilbene } \\
4.50 \\
3.75\end{array}$ & $\begin{array}{l}0.028 \\
0.043\end{array}$ & $\begin{array}{l}0.000 \\
0.018\end{array}$ & $\begin{array}{l}2.75 \pm 0.50 \cdots \\
5.00 \pm 0.82 \cdots\end{array}$ & $\begin{array}{l}2.31 \pm 0.31 \cdots \\
1.95 \pm 0.29 \cdots\end{array}$ \\
\hline $\begin{array}{l}4 \cdot(2 \cdot \text { Phenylethyi) } \\
100 \\
100\end{array}$ & anilite & 0.028 & 0.000 & $2.75 \pm 0.96$ & $2.31 \pm 0.39 * *$ \\
\hline $\begin{array}{l}100 \\
100 \text { - Einyte netesta }\end{array}$ & $\begin{array}{r}\text { anditre) } \\
3.00\end{array}$ & 0.020 & 0.000 & $2.00 \pm 0.82$ & $2.67 \pm 0.29 * *$ \\
\hline $\begin{array}{l}\text { 2-Avilingluth the } \\
100\end{array}$ & 6.00 & 0.048 & 0.005 & $5.25 \pm 1.26 \cdots$ & $2.70 \pm 0.47^{*}$ \\
\hline $\begin{array}{l}\text { 2,7-Diaminofluore } \\
100\end{array}$ & ene 3.75 & 0.045 & 0.003 & $4.75 \pm 0.96 * \pi$ & $2.57 \pm 0.36 * *$ \\
\hline $\begin{array}{l}\text { 4.Amino-2'-meth } \\
100\end{array}$ & $\begin{array}{l}\text { ylliphemyi } \\
2.50\end{array}$ & 0.033 & 0.0008 & $4.00 \pm 1.16 * *$ & $26 x \pm 0.36 \cdots$ \\
\hline $\begin{array}{l}\text { Positive control } \\
\text { DMBA (100 mB } \\
\text { / } \mathrm{kg})\end{array}$ & 11.25 & 0.115 & 0.023 & $13.25 \pm 0.96 * *$ & $2.13 \pm 0.12$ \\
\hline
\end{tabular}


scored with the aid of an Artex counter (Dynatech: Labs., Chantilly, VA) which had been calıbrated against manually scored plates.

\section{Chromosmal aberrations ( $C A$ )}

Test chemicals in DMSO at the concentrations shown in Table 3 were administered i.p. as single coses to each of 4 mice. Negative control mice were injected with $2 \mathrm{ml} / \mathrm{kg}$ DMSO while DMBA was used as a positive control at a dose of 100 $\mathrm{mg} / \mathrm{kg}$ in DMSO. CA assays were conducted as previously described (Giri et al., 1989) with a fixation timc of $24 \mathrm{~h}$ after injection which is cunsistent with the protocol of Preston ct al. (1987). This fixation time was found to be an optimal time for benzidine after testing at 6, 12 and $24 \mathrm{~h}$. All the slides were coded and observed by a single observer. 100 well-spread metaphase celis were scored per animal from each of 4 arimals at each concentration testcd. Mitotic indices were calculated from 1000 cells/animal and expressed as percentages. $C A$ were scored following the method of WHO (1985) and Preston et al. (1987). The aberration frequencies per cell for chromatid and chromosome types were calculated. Gaps were recorded (Table 3) but not included in the frequency of aberrations per cell.

\section{Results and discussion}

The i.s vitro results with Salmonella strains TA98 and TA100 are summarized in Table 2 . As noted in our previous study of benzidine analogs and from the well documented need for metabolic activation of aromatic amines to produce alkylating agents (Beland and Kadlubar, 1985), there was only limited activity in cither strain without S9 activation. The major exceptions were the two nitro derivatives, where the presence of a nitro reductase system in TA98 (Nohara et al., 1985) could explain the moderate mutagenicities of these compounds in this strain without 59 activation.

In general, $\pi$-orbital conjugation between the two phenyl rings is an important factor for mutagenicity in both strains with $\mathbf{S 9}$ activation. There is an increase in mutagenicity with an increase in planarity and its resulting increase in conjugation for the series 4-amino-2'-methylbiphenyl, 4aminobiphenyl and 2-aminofluorene. This is a series in which the parent compounds for these amines, 2-methylbiphenyl, biphenyl and fluorene have an angle betwecn the two rings of 58,23 and $0^{\circ}$ respectively (Suzuki, 1959a, b, c). Likewise, 2,7-diaminofluorene is more active than benzidine. Also, the extended conjugation of the stilbenes over their corresponding biphenylamines for the most part led to an increase in mutagenicity. The exception, in this regard, was the greater mutagenicity of 4-aminobiphenyl over 4-aminostilbene in both strains with activation. Elimination of conjugation between the phenyl rings in the stilbenes by saturation of the carbon-carbon double :zonu cleurly resulted in a decrease in mutagenicity for 4-(2-phenylethyl)aniline and 4,4'-ethylenebis(aniline) compased to the parent stilbencs.

The results in Table 2 indicate that the substituents in the 4'-position of both the biphenyl series and the stilbene series have an electronic effect on mutagenicity. With increasing clectron withdrawing capacity of these substituents, there is increasing mutagenicity in the order of $\mathrm{NH}_{2}<$ $\mathrm{H}<\mathrm{Cl}<\mathrm{NO}_{2}$. This relationship only holds in the tests with TA98 which detects frameshift mutations.

The in vivo genotoxicity of the aromatic amines under considcration as measured by $\mathrm{CA}$ in the hone-marrow cells of mice is summarized in Table 3. A dose-response relationship was established for the acute genotoxicity of benzidine in the range from 0 to $125 \mathrm{mg} / \mathrm{kg}$ of body weight. The acute genutoxicity of the other amines were compared to that of benzidine at 25 and/or 100 $\mathrm{mg} / \mathrm{kg}$. With the exception of $4,4^{\prime}$-ethylenebis(aniline), all compounds showed a significant $(p<0.05)$ increase in $C A$, at least at the 100 $\mathrm{mg} / \mathrm{kg}$ dose compared to the negative control.

Relative mutagenicities in the Ames test did not correlate to in vivo $C_{\lambda} I$ results. The effect of $\pi$-orbital conjugation was less pronounced in vivo than in vitro. Also, the increased effect on genotoxicity with increases in the electron withdrawing ability of substituents was not evident in vivo as it was in vitro. For example, the high mutagenicity for 4-amino-4'-nitrobiphenyl in comparison to the other biphenyls is in contrast to its lower ranking for $\mathrm{CA}$ rcsults. The outstanding difference in comparing the in vitro and in vivo 
results was the exceptionally high $\mathrm{CA}$ values for 4-aminostilbene. The CA results of 4-aminostilbene was much greater than those for any of the other compounds tested. This includes the well established carcinogen, DMBA, our positive control. All the conjugated mono-amino compounds had relatively high $C A$ values.

The significantly higher $C A$ values for the mono-amino compounds over their corresponding di-amino derivatives in the stilivene $(p<$ $0.001)$ and biphenyl $(p<0.05)$ series led to a review of the literature in regards to such comparisons. While there is an extensive literapure on the genotoxicity of 4-aminobiphenyl, benzidine and 2-aminofluorene, this is not tsue for 2,7-diaminofluorene nor 4-amino- or 4,4'-diaminostilbene (Sweet, 1987). Direct comparisons of these pairs of mono- and di-substituted amines are for the most part limited to the two biphenyl compounds and usually represent in vitro tests. As was confirmed in the present study, it is well established that 4-aminobiphenyl is more mutagenic than benzidine in the Ames test with standard rat $\$ 9$ activation (McCann et al., 1975; Bos et al., 1982; Nohara ct al., 1985; Messerly ct al., 1987). However, when activation in the Ames test was with rat liver hepatocytes, benzidine exhibited greater mutagenicity than 4-aminobiphenyl (Bos et al., 1982).

As is true in the present study, it has also been previously jeported that 2-aminofluorene in the Ames test with rat $\mathbf{S} 9$ activation has greater mutagenicity than 2,7-diaminofluorene (McCann et al., 1975; Vance et al., 1987). The same relationship holds when the activation is with microsomes from Drosophila (Nix et al., 1981) or with micro. somes from Salamanders (Anderson et al., 1982). Other in vitro studies of benzidine and 4aminobiphenyl have indicated 4-aminobiphenyl to be more genoloxic than benzidine on the basis of a DNA repair test (Althaus and Pitot, 1983) and by an alkaline clution assay with rat hepatocytes (Sina et al., 1983). However, these two compounds had about an equal response in a DNA damage-alkaline elution assay with Chinese hamster cells (Swenberg et al., 1976). In a DNA-cxcision repair assay with rat hepatocytes, be:zidinc gave a greater rise in unscheduled DNA synthesis than 4-aminobiphenyl (Brouns ct al., 1979).
Prior reports of the in vivo genotoxicity of the mono-amino vs. di-amino compounds examined in the present stidy also appear to be restricted to comparisons of benzidinc and 4-aminobipheny!. In their review of the literature, Arcos and Argus (1974) reached the conclusion that 4 aminobiphenyl is more genotoxic in vivo than benzidine as is the case for our bone-marrow studies. However, Parodi et al. (1982) calculated a greater oncogenic potency index for benzidine than for 4-aminobiphenyl and Bos et al. (1982) repurted greater genotoxicity for benzidine conpared to 4-amisobiphenyl in a host-mediatcd assay. A somewhat greater response for induced sister-chromatid exchange in vivo in the bone marrow of chinese hamsters has been reported for benzidine dihydrechloride compared to 4 aminobiphenyl at $50 \mathrm{mg} / \mathrm{kg}$ (Neal and Probat. 1983). At this dose, they also reponted a similar effect to that of 4-aminobiphenyl for 2-aminofluorene.

In general, literature reports of bone-marrow tests for aromatic amines in vivo are often inadequate (Mirkowa and Ashby, 1988) although they arc desirable to supplement Ames test resuits (Shelby, 1988). The present study extends such comparisons of results from the Ames test to those in vivo in bone marrow. The most evident difference in vivo was the exceptionally high genotoxicity of 4-aminostilbenc. This, together with the relatively high in vivo response for 4 aminobiphenyl and 2-aminofluorene, points out the potential for increased genotoxicity for those aromatic amines related to benzidine but without substitution in the para' position.

\section{Acknowledgements}

The investigation was supported by grant R01 ES05047 from the National Institute of Environmental Health Sciences, DHHS.

\section{References}

Athaus, F.R. and HI.C. Pitol (1983) A rapid lectnique for the quantitation of DNA-repair synthesis in the hepalocyte/ DNA-repair test for chemical carcinogens. Ann. N.Y. Acud. Sci, 407, 463-466.

Anderson, R.S. J.A. Döös and F.L. Rose (1982) Differential ability of Ambysioma tigninum hepatic mictusomes to pro. duce mutagenic metabolites from polycyclic aromatic hydrocarbons and aromatk amines, Canker Lett., 16, 33-41. 
Arcus. J.C., and M.F. Argus (1974) Chemical Induction of Concer, Vol. IIB, Academic Press, New York, pp. 33-51.

Beaven, G.H., P.B.D. De La Marc. M. Hassan, E A. Johnson and N,V, Kassen (1961) The kinetics and mechanisms of sromatic halogen substitution, Part $X$. Products in the chlorination of biphenyl in acelic acid, J. Chem. Soc., $2749-2753$.

Beland, F.A., and F.F. Kadlubar (1985) Formation and persis. tence of arylamine DNA adducts in vivo, Enviran. Health Perspecl., 62, 19-30.

Bos, R.P., R. van Doorn. E. Yih-van de Hurk, P.J.L. van Gemert and P.Th. Henderson (1982) Compasison of the mulagenicities of 4-aminobiphenyl and benzidine in the Salmonella / microsome, Salmonella/ hepatocyte and host-mediated assays, Mutation Res., 93, 317-325.

Bmuns, R.E., M. Poot, R. de Vind. Th.v. Huek-Kon and P.Th Henderson (1979) Mcasurement of DNA-excision repait in suspension of freshly isolated rat hepatocytes alter exposure to some carcinogenic compounds, Mutation Res., 64, 425-432.

Buckingham. J. (1982) Dictionary of Orgunic Cumpounds, 5th edn., Chapman and Hall, New York.

France, H., L.M. Heilbron and D.H. Hey (1939) Studies in the terphenyl series. Part 11. Hydroxy-and methyl-p-terphenyls, J. Chem. Soc., 1283-1287.

Geerts, J.P., and R.H. Martin (1960) Synthese dans le domanine des compose polycycliques aromatiques, Bull. Soc. Chim. Belges, 69, 563-569.

Giri, A.K., E.A. Messerly and J.E. Sinshejmer (1989) Sisterchromatid exchange and chromosom: aberrations for 4 aliphatic eporides in mice, Mutation Res., 224, 253-261.

Haley, TJ. (1975) Benzidine revisited: A review of the litera. lure and problems associated with the use of benzidine and its congeners, Clin. Toxicol., 8(1). 13-42.

Maron, D.M., and B.N. Ames (1983) Revised methods for the Sulmunella mutagenicity test; Mutation Res, 113, 173-215.

McCann, J., E Choi, E. Yamasaki and B.M. Ames (1975) Detection of carcinogens as mutagens in the Salmonella/ nicrosome test: assay of 300 chemicals, Proc. Nall. Acad. Sci. (U.S.A.), 72, 5135-\$139.

Messerly. E.A., J.E. Fekete. D.R. Wade and J.E. Sinsheimer (1987) Structure-mutagenicity relationships of benzidine analogues, Emviron. Mol. Mutagen., 10, 263-274.

Mirkowa, E., and J.Ashty (1988) Activity of the human cascinogen benzidine and 2-naphthylamine in make mouse bone marrow micronucleus assays, Mutagenesis, 3, 437439.

Natarajan, A.T., and G. Obe (1986) How do in vivo mam. malian assays compare to in vitro assays in their ability to detect mutngens?, Mutation Res., 167, 189-201.

Neal S.B., and G.S. Probat (1983) Chemically-induced sisterchromalid exchonge in vivo in bone marrow of Chinese hamsters, Mutation Res., 113, 33-43.

Nix, C.E., B. Brewen and J.L Epler (1981) Microsomal activation of selected pobycyelic aromatic mydrocacbons and aromatic amines in Drosophila melanosaster, Mutation Res., 88, 291-299.

Nohara, M., T. Hirayama, Y. Fujioka, S. Orasa, E. Ibuki and S. Fukui (195) Relationship between mutagenic potency in Salmonella oyphimurium and chemical structure of amino and nitro-substituted biptienyls, Mutation Res., 149, 9-15.

Parodi, S., M. Taningher and L. Santi (1982) Akaline elution in vivo: fluorometric analysis in rats quantitative predictiv. ity of carcinogeniciny, as compared with other short-term testy, in: B.A. Bridges, H.E. Butterworth and I.B. Weinstein (Eds.). Banbury Report 13, Indicalors of Genotoxic Exposure, Cold Spring Harbor Laboratory, New York, pp. 137-155.

Porcer, H.K (1973) The Zinin reduction of nitroarenes, Organic Reactions, 20, 455-481.

Preston, R.J. B.J. Dean. S. Galloway, H. Holden, A.F. McFee and M. Shejby (1987) Mammatian in vivo cytogenetic assays: Analysis of chromosome alerrations in bone marrow cells, Mutation Res., 189, 157-165.

Shetby, M.D. (1988) The genetic toxicity of human carcino. gens and its implications, Mulation Res., 204, 3-15.

Sina, J.F., C.L. Bean, G.R. Dysarl, V.I. Taytor and M.O. Bradley (1983) Evaluation of the alkaline elution/rat hepatocye assay os a predictor of carcinogenic/mulayenic putential, Mutation Res., 113, 357-391.

Suruki, H. (1959g) Relations between electmonic absorption spectra and spatial configurations of conjugated systems. I. Biphenyl, Bull. Chem.. Soc. (Japan), 32, 1340-1350.

Suzukj, H. (1959b) Relations hetween telectronic absorption spectra and spatial configurations of conjugated systems, II. o-Alkyl and o,o'-dialkyl biphenyls, Bull. Chem. Soc. (Japan), 32, 1350-1356.

Suzuki, H. (1959c) Relations between tekctrunic absopplion spectra and spatial contigurations of conjugated systems, III. $o, o^{\prime}$-Bridged biphenyk, Bull. Chem. Soc. (Japan), 32, 1357-1351.

Sweet, D.V. (19.87) Registry of Toxic Effects of Chemical Substances, 1985-86 edn., Vol. 2, U.S. Govemment Print. ing Oftice, Washington, DC.

Swenberg, J.A., G.L Petzold and P.R. Harboch (1976) In vitro DNA damage/alkaline elution assay for predicting carcinogenic potential, Bjochett. Biophys. Res. Commun., $72,732-738$

U.S. Federal Register (1974) (part III) No. 20, Carcinogens Occupational Healto Safely Standards, 39, 3755-3797.

Vance, W.A. Y.Y. Wang and H.S. Okamoto (1987) Disubstituted amino*, nitroso-, and nitrofuorenes: a physicochemical basis for structure-activity relationships in Salmonella trphimurium, Environ. Mulagen., 9, 123-141.

Veschambre, $H_{\text {. }}$ and A. Kergomard (1966) Transmission of electronic effects in substituted trans-stilbenes, Bull. Soc. Chem. (France), 1, 336-342.

Weast, R.C., and J.G. Grasselli (1981) Handbook of Dela on Organic Compounds, 2nd edri, CRC Press, Boca Raton.

World Health Organization (1S85) Environmental Health Cri. teria, 46. Guidelines for the Sludy of Genetic Effects in Human Populations, WHO, Geneva.

Zaron, M.R., Y. Hoegg and E. Bingman (1973) Benzidine ixposure as a cause of bladder tumors, Arch. Environ. Health, 27, $1-8$.

Zheltow, A.Y., V.Y. Rodionow and B.I. Stepanov (1970) Invesligations on aromatic disulfides, IlI. Basicity and structure of substituted 4 and 5-aminobiphenylene-2,2'-disuliide, Zhur. OTB. Khim., 6, 2562-2569. 